\title{
Brezhnev counts on Academy of Sciences to organise applied research
}

LAST month, the Soviet Academy of Sciences met to discuss the role of scientists in solving the urgent problems facing the national economy. This was on instructions from the Party Central Committee and the government, and was a response to $\mathrm{Mr}$ Brezhnev's November address to the Central Committee. In his swingeing attack on Soviet planning and production, Brezhnev singled out for castigation a number of ministries (including railways, power and ferrous metallurgy), the State Planning Committee and the "bureaucratic and local interests" which "weaken the strength of the plan". In tackling the "vital tasks", both of production and planning, said Brezhnev, the Party counts on the active assistance of scientists, the USSR Academy of Sciences, the Republic and branch academies and all scientific research institutes. "The State Committee for Science and Technology", he added, "must also work in a more energetic manner".

This is not the first time that Brezhnev has called on the academy for assistance. At the Twenty-Fifth Party Congress in 1976 , he had declared that the academy was to act as cheif coordinator of all scientific work in the country. This caused some confusion, not least to the academicians themselves. It now seems certain, however, that what Brezhev meant was that the academy should coordinate fundamental research throughout the USSR, stressing the need to implement the practical applications of such research.

At the same time, a number of specialists from the academy were involved (together with officials of the State Planning Committee, the relevant ministries and the State Committee for Science and Technology) in working out a "complex programme" for the development of science and technology up to 1990 . Work on this programme began in 1972, under the general direction of a special commission of the academy presidium, but by summer 1979 it was still not completed. In the course of work on the "complex programme", there have been numerous set-backs; perhaps the greatest being the change from forecasts for individual technologies with little coordination between them (some 150 in the first drafts) to 25 "integrated" programmes, 17 for science and technology and eight for social questions, covering broader fields such as energy, health, industrial materials, and demographic trends.

How far existing plans for the "complex programme" will be affected by the latest appeal to the academy is not clear.
Addressing the assembly, the President of the academy, Anatolii P. Aleksandroy stressed the Soviet Union's continuous shortfall of ferrous metals, cement and fertiliser, the need to pay greater attention to the "economic utilisation" of energy, raw materials and agricultural produce.

Nikolai Baibakov, Chairman of the State Planning Committee and a Deputy Chairman of the USSR Council of Ministers, stressed the need for a long-term comprehensive programme for transport, including pipelines for pulp, pipelines using containers, magnetic suspension transport and linear motor trains. The automation of manual labour (a major problem for the Soviet Union with its falling demographic trend) was also stressed. Baibakov commended the academy's current research on energysaving types of equipment and new types of polymer, which, he said, should ultimately save the economy some 1000 million roubles.

Media comments on the session, presumably from official releases, stressed the need for a new comprehensive plan for science and technology up to the year 2000 , giving priority to new regions in the far north, Siberia, and the Soviet Far East.

Setting the tone for such developments, Baibakov noted that "socialist planning has always been 'target-orientated", citing Lenin's plan to electrify the whole country, the construction of heavy industry in the 1930s, the Virgins lands scheme of the early 1960 s, and the current construction of the Baikal-Amur Mainline railway.

His remarks have some suggestion that science and technology might take on the status of a "crash programme". (This would not be out of key with the economic "mini-reform"' proposed last July). Aleksandrov, the President of the Academy has, incidentally, considerable experience of this type of priority development (nuclear research) as had his predecessor Mstyslav Keldysh (space). Such crash programmes have been particularly successful in sectors with some defence connections (since defence falls outside the main planning structure). Any attempt to introduce wide-scale crash planning would, however, appear to be counter-productive - there would be too many priorities competing for too few resources.

The main weakness of Soviet science planning, however, remains the point at which production takes over from research. Since the mid 1960s the planners have set considerable store on closer links between research and academic institutes on the one hand, and local farms or factories on the other. The classic case of such cooperation is the Siberian branch of the academy at Novosibirsk. Here a network of research institutes, design centres and experimental production factories has been set up. These are maintained by, and officially subordinate to, the relevant ministries, but the various institutes of the Academy of Sciences are responsible for the scientific leadership.

Recently, a number of ad hoc "science centres" were established throughout the Soviet Union, often simply by formally linking existing research and industrial establishments. Many of these centres, Baibakov told the academy, are "observed to be dissipating their resources" and wasting time on "second grade problems", which are not "in the mainstream of technical progress". As a result, "many ministries (presumably those censured by Brezhnev) have been unable to fulfil their plans for science and technology".

Since the Siberian branch of the academy was established, a number of academics, including its chairman academician G I Marchuk, have pointed out that the dual control system could lead to precisely this kind of dissipation. However, this has always been presented as a danger. By concentrating too much on the minutiae of day-to-day problems, the ministry could distract researchers and resources from basic and far-reaching tasks. Academician B Paton of the Ukrainian Academy of Sciences would prefer that even the design and pilotproduction facilities should be subordinate to the academy, so as to obviate this hazard.

Baibakov's remarks, however, seem intended to exonerate the ministry planners and, perhaps, by implication, shift a greater responsibility to the academics. The relationship between the Academy of Sciences (traditionally orientated to fundamental research) and the state committee for Science and Technology, with its stress on production is always a delicate one. Although Brezhnev has censured the state committee and called once again on the academy's assistance, the state committee has recently taken over a duty which would normally be considered the prerogative of the academy. At the forthcoming Hamburg "scientific forum", where most of the Helsinki signatories will be represented by their academies of science, the Soviet delegation will be headed by the Chairman of the State Committee. 